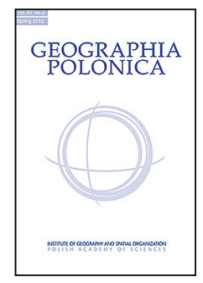

\title{
THE VARIABILITY OF DAILY PRECIPITATION TOTALS IN POLAND (1951-2000)
}

\author{
JOANNA WIBIG \\ Department of Meteorology and Climatology, University of Łódź \\ Narutowicza 88, 90-139 Łódź, Poland \\ E-mail: zameteo@uni.lodz.pl
}

\begin{abstract}
The analysis concerned the variability of daily precipitation totals observed during the second half of the 20th century at five stations in Poland. The elements examined were number of days with precipitation exceeding given thresholds, lengths of wet and dry spells and precipitation amounts in a single spell. There is an upward trend for the number of spells and days with precipitation, and a downward trend for mean precipitation during a given spell. Changes in peak precipitation are not uniform, there being negative trends at some stations and positive ones at others. However the lack of a trend for precipitation totals combines with the climatic warming now to be observed to imply risk of a water deficit.
\end{abstract}

key words: wet spell, dry spell, precipitation extremes, linear trend, Poland

\section{INTRODUCTION}

Many studies have reported increased precipitation in the mid to high latitudes of the Northern Hemisphere over the last century. An increase of $10-50 \%$ has been observed over Northern and Western Europe (Watson et al., 1998). In Poland, a slight increase in precipitation totals can also be observed, but one that does not exceed the level of significance (Kożuchowski 2004). As the Third Assessment IPCC Report (Houghton et al. 2001) warns against a higher risk of floods and droughts occurring more often in a warmer world. This study focuses on variations in daily precipitation totals and the way they are related to atmospheric circulation indices.

\section{DATA AND METHODS}

Use was made of daily precipitation totals for the period 1951-2000 at five stations in Poland: Szczecin in the north-west, Suwałki in the north-east, Przemyśl in the south-east, Wrocław in the south-west and Łódź in the centre (Fig. 1). Daily gridded geopotential heights at the $700 \mathrm{hPa}$ level from NCEP/

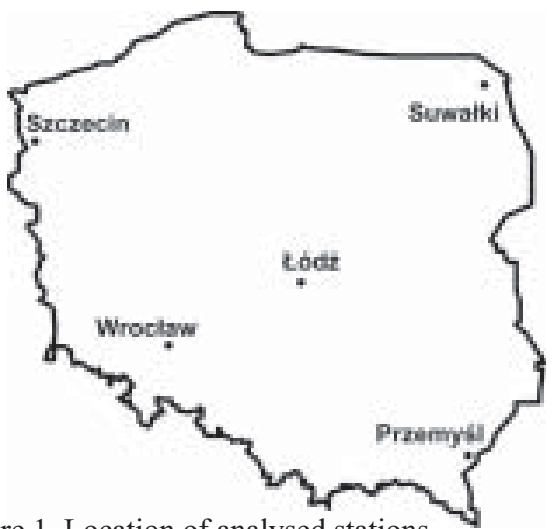

Figure 1. Location of analysed stations. 

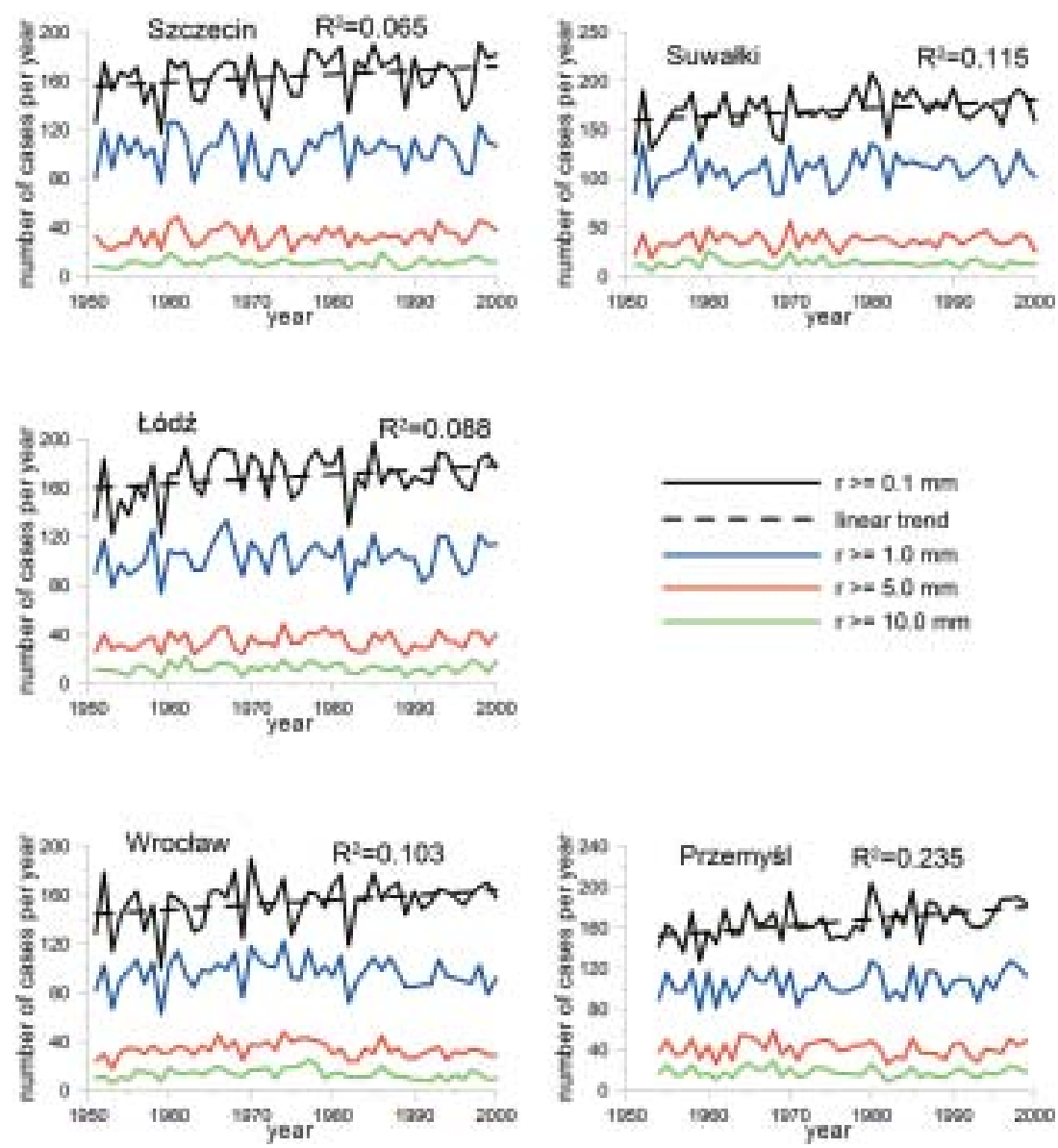

Figure 2. Annual number of days with precipitation exceeding selected thresholds: $\geq 0.1, \geq 1.0, \geq 5.0, \geq 10.0$ $\mathrm{mm}$ with linear trend and determination coefficient $\left(\mathrm{R}^{2}\right)$ of number of rainy days, during the period 1951-2000.

NCAR reanalysis (Kalnay et al., 1996) were used to analyze the influence of circulation on the occurrence of heavy precipitation events.

Two large European projects analyzing daily precipitation totals in the context of extreme events are: the European Climate Assessment (Klein Tank, A.M.G. Können, 2003) and EMULATE (Moberg et al., 2006). Among the indices suggested by these groups are the highest daily total in the year, the numbers of days with precipitation exceeding thresholds defined by percentiles ( 75 , $90,95,99)$ during a selected reference period, or by given values, and the fraction of precipitation totals noted on days with precipitation exceeding these thresholds. From among these indices, this study applied: the highest daily total and annual frequencies of days exceeding selected thresholds. Because the area of interest is not large, the thresholds common to all stations used were: $0.1 \mathrm{~mm}$ - measureable precipitation, $1.0 \mathrm{~mm}$ - slight precipitation, $5.0 \mathrm{~mm}$ - moderate precipitation and $10.0 \mathrm{~mm}$ - high precipitation.

On that basis, the annual frequencies of wet days $(r>0.0)$, and the $1,5,10,25,50,75,90$, 95 and 99 percentiles for all wet days $(r>0.0)$ were determined for each year separately, and trends therefore analysed (section 3 ).

The wet spells (section 4) and dry spells (section 5) were analysed in relation to changes in their length and intensity. 

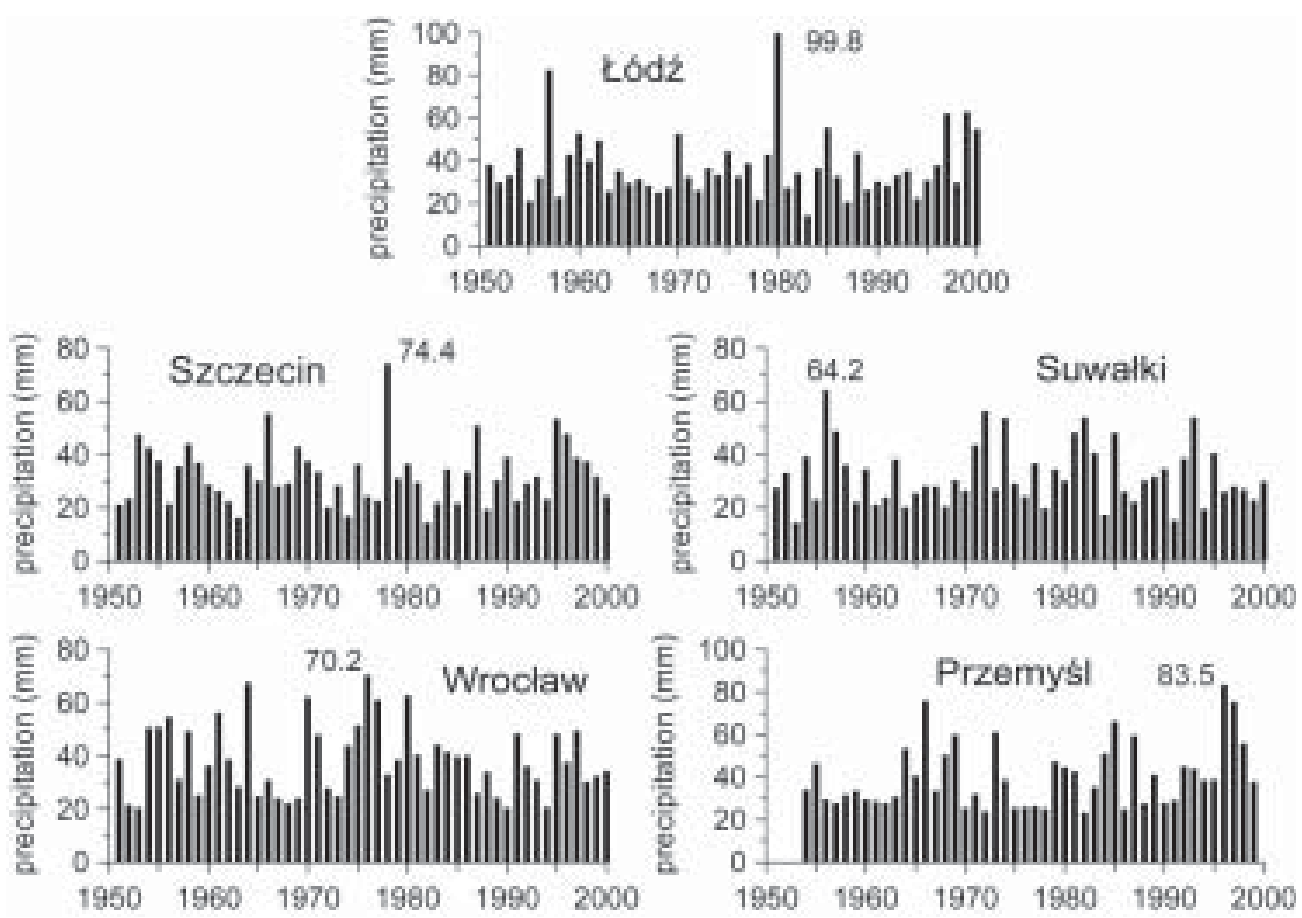

Figure 3. The highest daily total in a year, 1951-2000.

The synoptic situations favorable to high precipitation events were also analysed. To do this the sample of days with precipitation $\geq 20 \mathrm{~mm}$ at at least one station was chosen and the Lund method of field classification (Lund, 1963) used to distinguish the synoptic situations favorable to high precipitation events (section 6). In this classification, geopotential heights at the $700 \mathrm{hPa}$ level on each selected day are correlated with those on all other days. The map with the highest number of correlation coefficients exceeding the given threshold (here 0.7 ) is selected and designated as type A. All days of this type (correlating with type A above the threshold) are removed from the sample and a next map with the highest number of correlation coefficients exceeding the given threshold is selected and designated as type B. The procedure is repeated until there are maps which correlate on the level exceeding the threshold.

Two methods were used to estimate linear trends and their statistical significances: the least squares method with Student t-test

(which assumes that the data distribution is close to normal) and the Sen's slope method with Kendall tau test (Sen 1968), which does not make any assumption as regards data distribution.

\section{DAILY PRECIPITATION TOTALS}

The annual frequencies of days with precipitation exceeding selected thresholds were analysed (Fig.2). The four thresholds selected were: $0.1 \mathrm{~mm}$ - measureable precipitation, $1.0 \mathrm{~mm}$ - slight precipitation, 5.0 $\mathrm{mm}$ - moderate precipitation and $10.0 \mathrm{~mm}$ - high precipitation. Only the frequency of wet days has increased significantly at all analysed stations. This increase varied from 3.2 days per decade in Szczecin to 6.2 days per decade in Przemyśl.

In each year the percentiles $1,5,10,25$, $50,75,90,95$ and 99 of all wet days ( $r>0.0)$ were calculated and tested against the trend. The results are as presented in Table 1. The 
Table 1. The trend coefficients in mm per decade of mean annual values of selected percentiles. Values significant at 5\% (10\%) level are bolded (in italic)

\begin{tabular}{lccccccccc}
\hline percentiles & 1 & 5 & 10 & 25 & 50 & 75 & 90 & 95 & 99 \\
\hline Wrocław & 0.00 & $\mathbf{- 0 . 0 1}$ & $\mathbf{- 0 . 0 2}$ & $\mathbf{- 0 . 0 4}$ & -0.06 & -0.15 & $\mathbf{- 0 . 3 3}$ & -0.10 & -0.23 \\
Przemyśl & 0.00 & $\mathbf{- 0 . 0 1}$ & $\mathbf{- 0 . 0 2}$ & $\mathbf{- 0 . 0 4}$ & -0.07 & $\mathbf{- 0 . 2 7}$ & $\mathbf{- 0 . 4 0}$ & -0.54 & 0.63 \\
Suwałki & 0.00 & $\mathbf{- 0 . 0 1}$ & $\mathbf{- 0 . 0 1}$ & $\mathbf{- 0 . 0 3}$ & -0.03 & -0.02 & -0.19 & -0.39 & -0.51 \\
Szczecin & 0.00 & $\mathbf{- 0 . 0 1}$ & $\mathbf{- 0 . 0 2}$ & $\mathbf{- 0 . 0 4}$ & -0.05 & 0.01 & 0.12 & 0.07 & 0.60 \\
Lódź & 0.00 & 0.00 & 0.00 & 0.00 & -0.02 & 0.03 & -0.05 & 0.05 & -0.18 \\
\hline
\end{tabular}
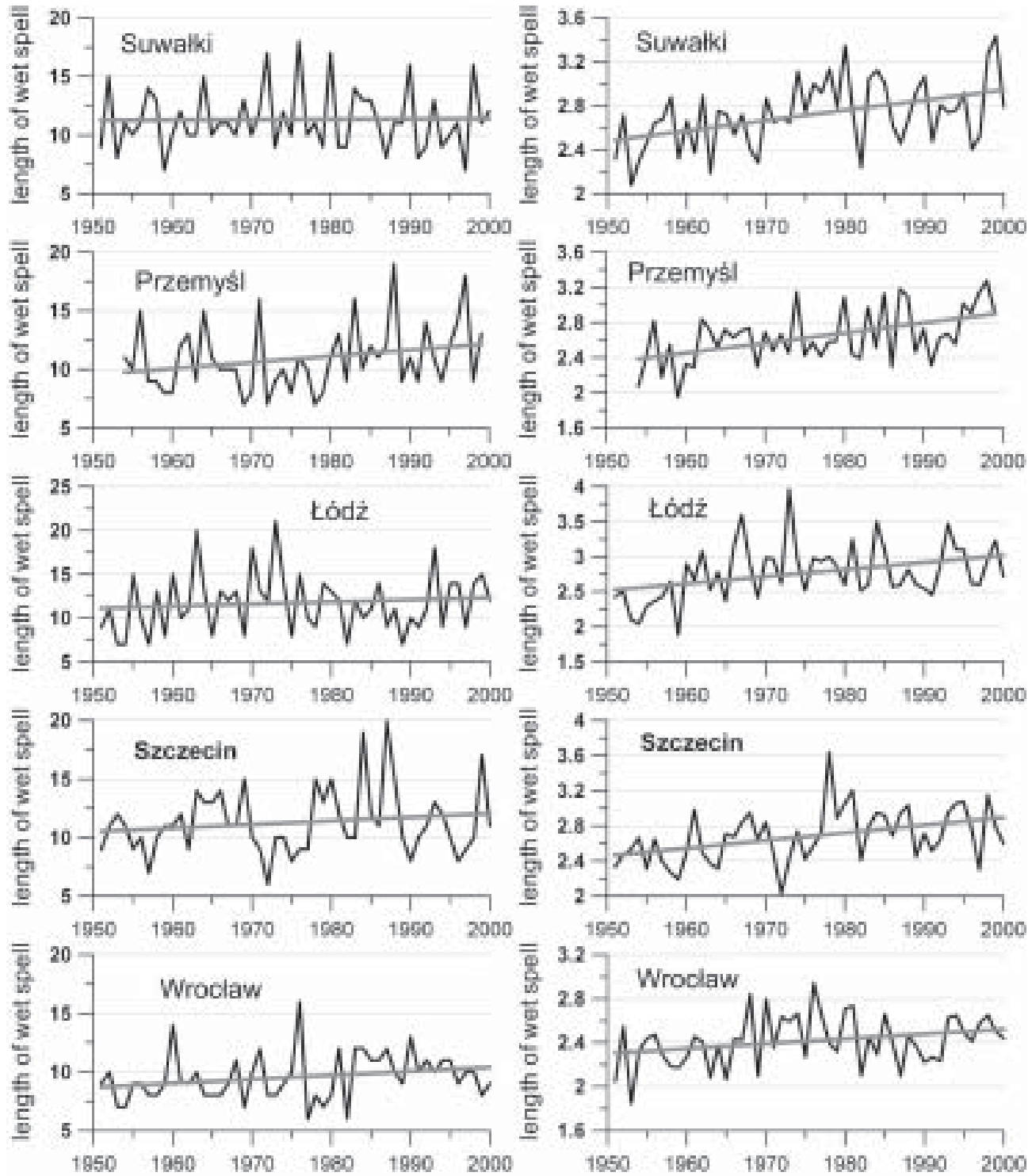

Figure 4. The longest wet spell in a year (left column) and the mean annual length of wet spell (right column) with linear trend estimated by the least square method and determination coefficient $\mathrm{R}^{2}$, during the period 1951-2000. 

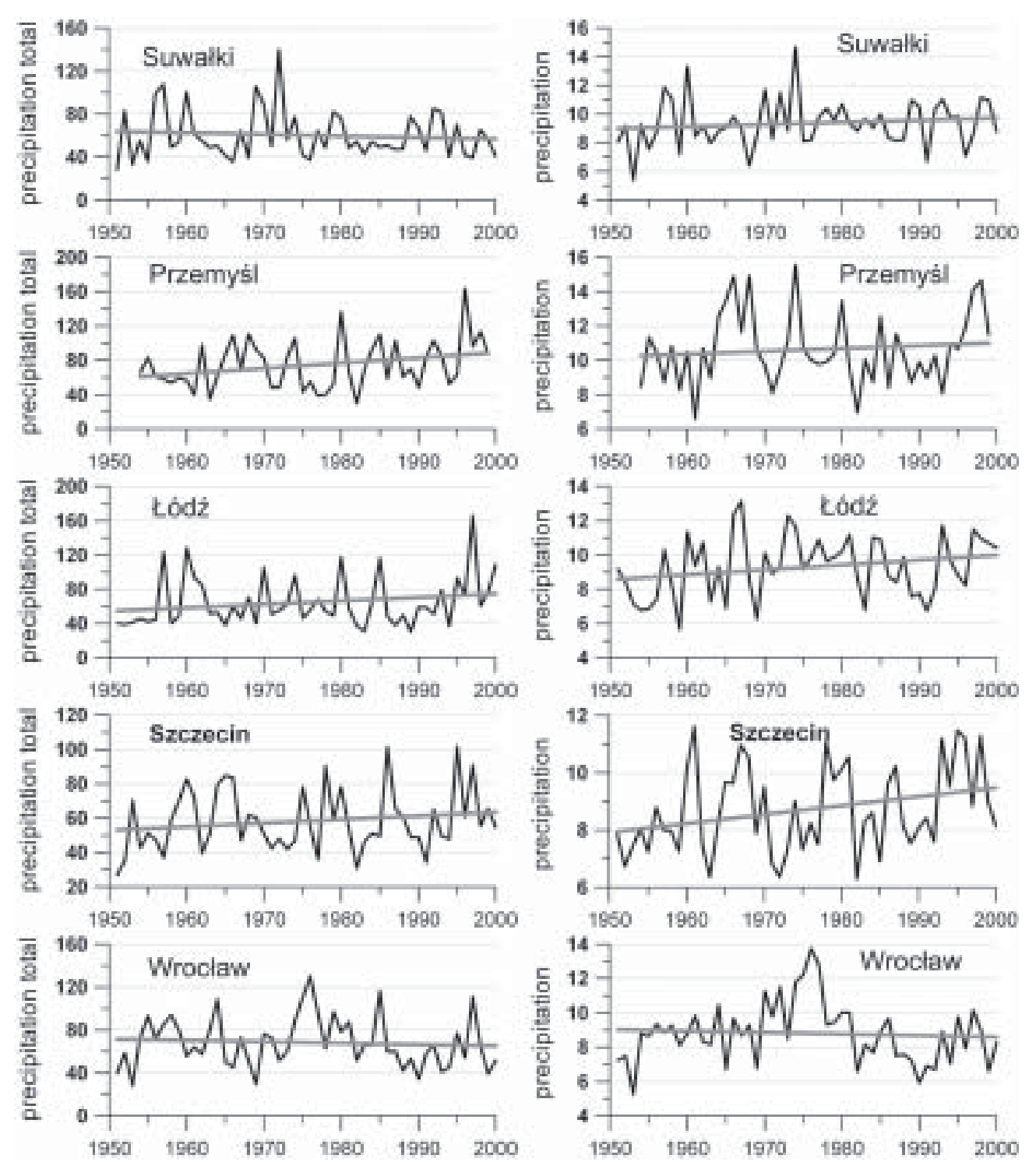

Figure 5. The highest precipitation total during one wet spell in a year (left column) and the mean annual precipitation total during one wet spell (right column) with linear trend estimated by the least square method and determination coefficient $\mathrm{R}^{2}$, during the period 1951-2000.

low percentiles $(5,10$ and 25$)$ have decreased significantly at the $95 \%$ level at four of the five stations. This means that lower daily totals have become more frequent. For higher percentiles negative trends still prevailed. A few positive trends were found, but these were not statistically significant.
The long-term course for highest daily precipitation totals at selected stations is as presented in Fig. 3. Only the record from Przemyśl reveals a slight upward trend (3.15 $\mathrm{mm} /$ decade). Changes were not observed at other stations. The highest daily totals varied from $64.2 \mathrm{~mm}$ in Suwalki to $99.8 \mathrm{~mm}$ in 


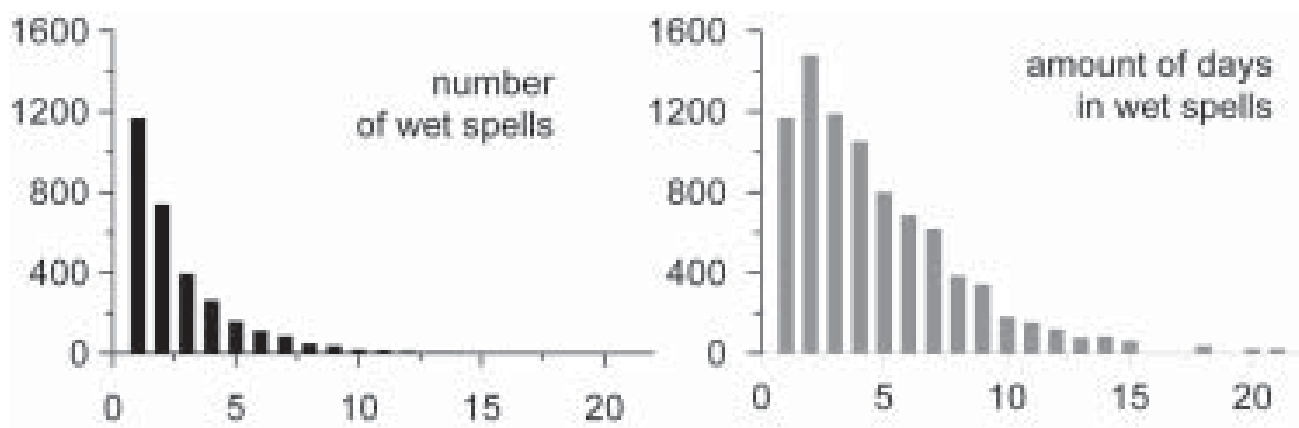

Figure 6. Number of wet spells in function of their length (left graph) and the amount of days in wet spell in function of their length (right graph) at Łódź in the period 1951-2000.

Table 2. Mean, standard deviation, maximum and minimum of mean annual length of wet spell and the longest wet spell in the year, the highest annual precipitation total during one spell and mean annual precipitation total during one spell in the period 1951-2000

\begin{tabular}{llccccc}
\hline & & Wrocław & Szczecin & Łódź & Przemyśl & Suwałki \\
\hline length of a wet & mean & 2.4 & 2.7 & 2.8 & 2.7 & 2.7 \\
spell & st. deviation & 0.23 & 0.31 & 0.40 & 0.32 & 0.30 \\
& maximum & 2.9 & 3.6 & 4.0 & 3.3 & 3.4 \\
& minimum & 1.8 & 2.0 & 1.9 & 2.0 & 2.1 \\
\hline length of the & mean & 9.6 & 11.3 & 11.7 & 11.0 & 11.3 \\
longest spell in the & st. deviation & 2.00 & 2.81 & 3.34 & 2.83 & 2.62 \\
year & maximum & 16 & 20 & 21 & 19 & 18 \\
& minimum & 6 & 6 & 7 & 7 & 7 \\
\hline precipitation total & mean & 8.8 & 8.7 & 9.3 & 10.7 & 9.4 \\
in a spell & st. deviation & 1.8 & 1.5 & 1.8 & 2.1 & 1.7 \\
& maximum & 13.7 & 11.6 & 13.1 & 15.5 & 14.6 \\
the highest & minimum & 5.3 & 6.3 & 5.6 & 6.6 & 5.4 \\
precipitation total & mean & 68.3 & 58.4 & 64.5 & 75.1 & 60.4 \\
in a spell & st. deviation & 23.4 & 18.0 & 29.4 & 28.1 & 23.0 \\
& maximum & 130.1 & 101.9 & 166.0 & 163.2 & 139.9 \\
& minimum & 28.2 & 27.1 & 30.6 & 29.7 & 28.1 \\
\hline
\end{tabular}

Łódź. Only in Przemyśl did the highest observed value occur in the last decade. These results are consistent with findings obtained by Moberg et al. (2006) and Klein Tank and Können (2003), who analysed indices for precipitation extremes in Europe, and did not note significant changes in Poland.

\section{WET SPELLS}

Wet spells were defined as uninterrupted sequences of days with daily precipitation $>0$. The mean annual number of such spells was slightly greater than 60 . The lowest annual numbers of spells varied from 31 at Przemyśl to 54 at Suwałki. The highest number of spells in turn varied from 73 at Suwałki and Szczecin to 81 at
Wrocław. The mean annual length of a wet spell was between 2.4 days in Wrocław and 2.8 in Łódź, but it could even reach 4 in particular years (Table 2). The longest annual wet spells were of 6 to 21 days, with mean values varying from 9.6 in Wrocław to 11.7 in Łódź. There is a downward trend for annual frequencies of wet spells, at four of the five analyzed stations. Together with trends for an increase in the number of wet days, this has resulted in longer mean lengths of wet spells (Tables 3 and 4). The slope estimators calculated by two methods give similar results. The magnitude of this increase is of about 0.09 days per decade. An upward trend can also be noted for in the length of the longest wet spell of the year. In this case the distribution of data is 

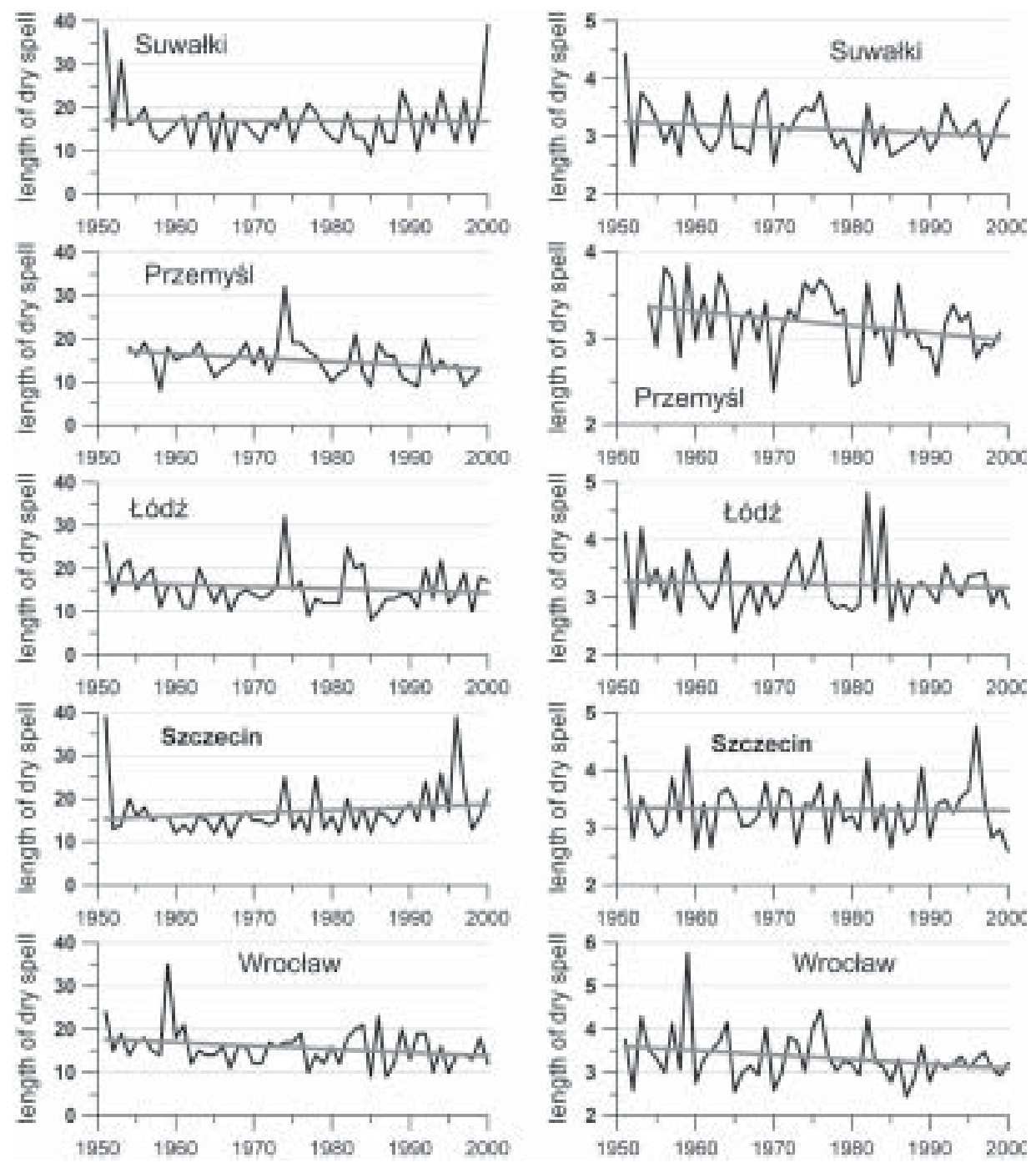

Figure 7. The longest dry spell in a year (left column) and the mean annual length of dry spell (right column) with linear trend estimated by the least square method and determination coefficient $\mathrm{R}^{2}$, during the period 1951-2000.

far from normal and the slopes estimated by the two methods differ significantly, the Sen's slope estimates seeming to be more robust (Fig. 4).

The distribution of wet spells in relation to their length shows that one-day wet spells are most common. However, the greatest number of days are included among wet spells lasting two days. An example of the distribution of wet spells in relation to their length and of the distribution of numbers of days in wet spells in relation to wet spell length is presented in Fig. 6.

Precipitation totals during particular wet spells can have a major impact on flooding. Mean precipitation totals in a spell varied from 5.3 to $15.5 \mathrm{~mm}$ (Table 2, Fig. $5)$, but from the point of view of flood risk 

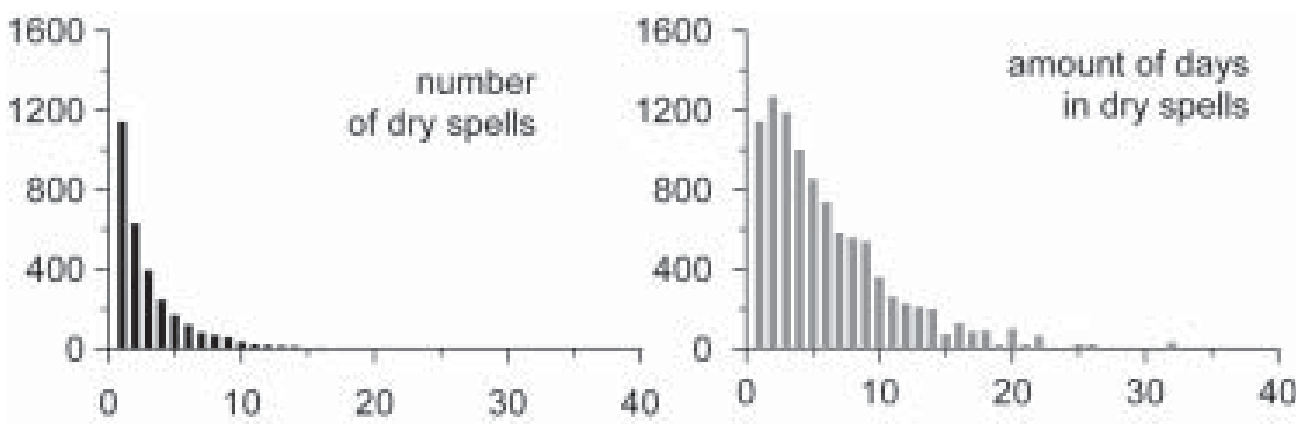

Figure 8. Number of dry spells in function of their length (left graph) and the amount of days in wet spell in function of their length (right graph) at Łódź in the period 1951-2000.

Table 3. Sen's estimate of slope in linear regression of selected features of wet spells * - significant at $90 \%$ level, ** - significant at $95 \%$ level

\begin{tabular}{|c|c|c|c|c|c|c|}
\hline element & unit & Wrocław & Szczecin & Łódź & Przemyśl & Suwałki \\
\hline number of spells & cases/decade & $0.31 *$ & $-0.89^{*}$ & $-0.96 *$ & $-0.63 * *$ & $-0.63^{*}$ \\
\hline the longest & & 0.3 & 0.00 & 0.00 & & 0.00 \\
\hline mean length of a spell & days/decade & $0.03 *$ & $0.09 * *$ & $0.09 * *$ & $0.10 * *$ & $0.09 * *$ \\
\hline the highest precipitation in a spell & & $-3.25^{*}$ & $1.38^{*}$ & $3.4^{*}$ & $5.8 * *$ & $-1.73 *$ \\
\hline mean precipitation in a spell & IIII/ Ce & $-0.15^{*}$ & $0.32 * *$ & $0.32 *$ & $0.17 *$ & 0.20 \\
\hline
\end{tabular}

Table 4. The least square estimate of slope in linear regression of selected features of wet spells * - significant at 90\% level, ** - significant at 95\% level

\begin{tabular}{|c|c|c|c|c|c|c|}
\hline element & unit & Wrocław & Szczecin & Łódź & Przemyśl & Suwałki \\
\hline the longest spe & \multirow{2}{*}{ days/decade } & $0.35^{*}$ & 0.31 & 0.24 & $0.53 *$ & 0.03 \\
\hline mean spell & & $0.04 * *$ & $0.09 * *$ & $0.10^{* *}$ & $0.11 * *$ & $0.09 * *$ \\
\hline the highest precipitation it & \multirow{2}{*}{$\mathrm{mm} /$ decade } & -1.29 & 2.11 & 4.0 & $6.11 * *$ & $-1.45^{*}$ \\
\hline mean precipitation in a spell & & -0.09 & $0.31 * *$ & $0.28 *$ & 0.16 & 0.15 \\
\hline
\end{tabular}

Table 5. Annual mean, standard deviation, maximum and minimum of number of dry spells, mean annual length of dry spell and the longest dry spell in the period 1951-2000

\begin{tabular}{llccccc}
\hline & & Wrocław & Szczecin & Łódź & Przemyśl & Suwałki \\
\hline number & mean & 64.0 & 61.3 & 61.5 & 62.4 & 62.8 \\
of spells & st. deviation & 5.98 & 5.40 & 5.98 & 6.41 & 4.56 \\
& maximum & 81 & 73 & 76 & 74 & 73 \\
& minimum & 46 & 49 & 45 & 31 & 54 \\
\cline { 2 - 7 } length of dry & mean & 3.4 & 3.3 & 3.2 & 3.2 & 3.1 \\
spell & st. deviation & 0.59 & 0.49 & 0.51 & 0.38 & 0.43 \\
& maximum & 5.8 & 4.8 & 4.8 & 3.9 & 4.4 \\
length of the & minimum & 2.4 & 2.6 & 2.4 & 2.4 & 2.4 \\
longest spell & mean & 15.8 & 17.1 & 15.5 & 15.0 & 16.9 \\
in a year & st. deviation & 4.52 & 5.79 & 4.7 & 4.20 & 6.16 \\
& maximum & 35 & 39 & 32 & 32 & 39 \\
& minimum & 9 & 11 & 8 & 8 & 9 \\
\hline
\end{tabular}



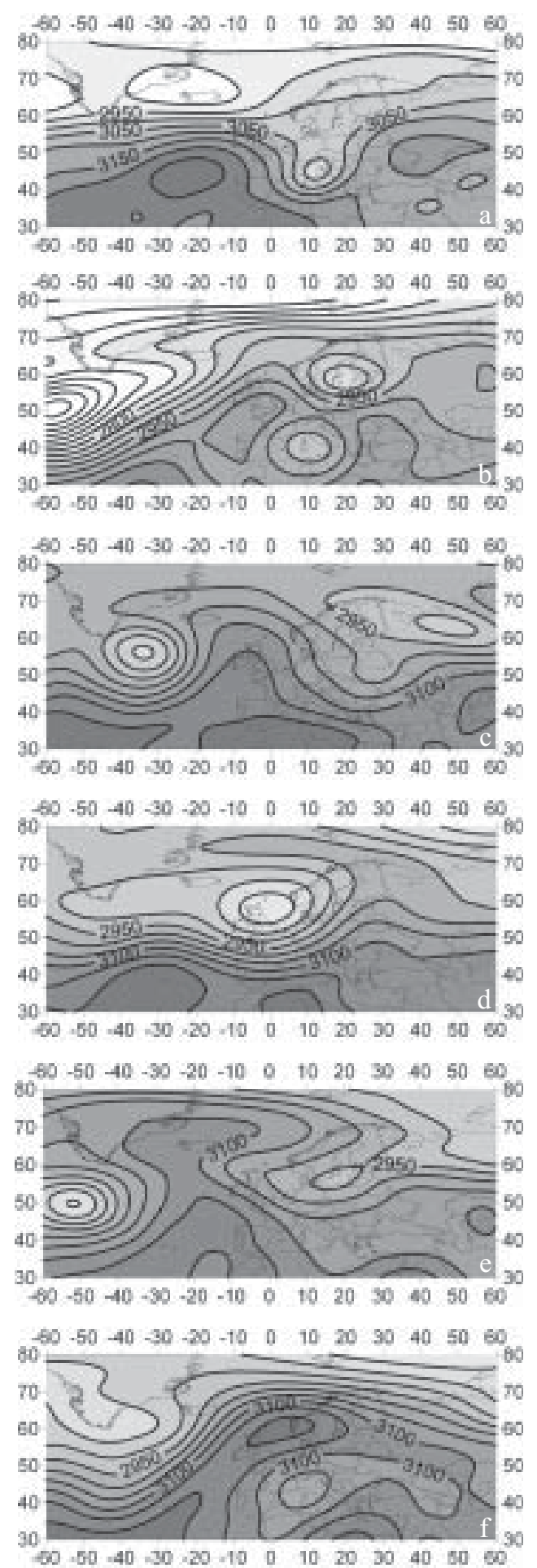

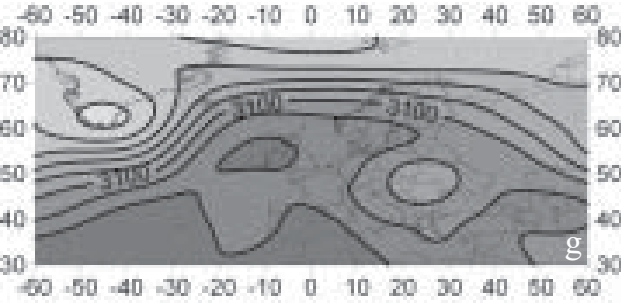

Figure 9. Synoptic types distinguished by Lund method at the $700 \mathrm{hPa}$ level.

the maximum annual precipitation totals during a spell are more interesting. In the analyzed period these varied from 18.0 $\mathrm{mm}$ to $166.0 \mathrm{~mm}$. At each of the tested stations maximum values were greater than $100 \mathrm{~mm}$. Mean precipitation during a given spell has increased significantly at four of the five stations. Both methods indicate that the increase is of the order of $0.2-0.3 \mathrm{~mm}$ per decade. Trends for highest precipitation during a single spell are positive at three stations and negative at two others. Slope estimates obtained by each method differ significantly. As previously those assessed by Sen's method seem more robust, since the method make no assumptions regarding the distribution of data.

\section{DRY SPELLS}

Dry spells were defined as uninterrupted sequences of days with zero daily precipitation. In line with this definition, days without precipitation and days with a so-called trace of precipitation are classified as dry. The annual number of dry spells is nearly equal (+/- 1 spell) to the annual number of wet spells, because they follow one after another. The mean length of a dry spell is close to 3.3, but in particular years and at particular stations it can vary from 2.4 to 5.8 (Table 5). Trends for the mean length of a dry spell are not uniform, and even their signs change from station to station.

More interesting from the point of view of drought risk is the length of the longest dry spell. The mean annual length of the longest dry spell varied from 15.0 to 17.1 , but the in- 
Table 6. Sen's estimate of slope in linear regression of selected features of dry spells

* - significant at $90 \%$ level, ** - significant at $95 \%$ level

\begin{tabular}{ccccccc}
\hline element & unit & Wrocław & Szczecin & Łódź & Przemyśl & Suwałki \\
\hline number of spells & cases/decade & $0.39^{*}$ & $-0.89^{*}$ & $-1.00^{*}$ & $-0.67^{* *}$ & $-0.67^{*}$ \\
the longest spell & days/decade & $-0.38^{*}$ & 0.67 & $-0.28^{*}$ & $-1.05^{*}$ & 0.00 \\
mean length of a spell & & $-0.05^{*}$ & $0.003^{*}$ & $0.003^{*}$ & $-0.10^{* *}$ & $-0.01^{*}$ \\
\hline
\end{tabular}

Table 7. The least square estimate of slope in linear regression of selected features of dry spells * - significant at 90\% level, ** - significant at 95\% level

\begin{tabular}{ccccccc}
\hline element & unit & Wrocław & Szczecin & Łódź & Przemyśl & Suwałki \\
\hline the longest spell & \multirow{2}{*}{ days/decade } & $-0.08^{*}$ & 0.66 & -0.47 & $-0.89^{* *}$ & -0.07 \\
mean length of a spell & $-0.10^{*}$ & -0.01 & -0.02 & $-0.108^{* *}$ & -0.05 \\
\hline
\end{tabular}

dividual values ranged from 8 to even 39 . At each station the longest dry spell during the second half of the 20th century was higher than 30 . The trends for the longest dry spell during the year were not uniform. Downward trends were observed at three stations, upward ones at one, while at one there was no change (Tables 6 and 7, Fig. 7).

The distribution of dry spells in relation to length shows that one-day dry spells are commonest, though the greatest number of days are in dry spells lasting two days. An example of the distribution of dry spells in relation to their length and the distribution of the number of days in dry spells in relation to dry spell length is presented in Fig. 8.

\section{ON THE DEPENDENCE OF EXTREME PRECIPITATION EVENTS ON ATMOSPHERIC CIRCULATION.}

Many authors have pointed to the strong influence of atmospheric circulation on precipitation in Europe (i.e. Hurrell and van Loon, 1997, Wibig 1999, 2001, Haylock and Goodess, 2004), and in Poland (Wibig, 2004, Paszyński and Niedźwiedź, 1999). But only some of these papers have concentrated on precipitation extremes (Paszyński and Niedźwiedź, 1999, Haylock and Goodess, 2004). In this section an attempt was made to distinguish the synoptic types occurring on days with heavy rainfall. The set of 648 days with daily precipitation totals exceeding 20 $\mathrm{mm}$ at at least one of the analyzed stations in the period 1958-2005 (the range of geopotential height data) was established, together with the appropriate set of geopotential high at the $700 \mathrm{hPa}$ level over the area ranging from $30^{\circ} \mathrm{N}$ to $80^{\circ} \mathrm{N}$ in latitude and from $60^{\circ} \mathrm{W}$ to $60^{\circ} \mathrm{E}$ in longitude with a step of $2.5^{\circ}$ in both directions. The synoptic types accompanying heavy rainfall situations in Poland were then classified using the Lund method. Seven types were distinguished, and more than $86 \%$ of selected days found to belong to one of these types. The model fields are as presented in Fig. 9, and the details summarized in Table 8.

The first type included more than $25 \%$ of all days with heavy precipitation. It presents intense zonal circulation with a wedge of low pressure over Central Europe. The second type, occurring on $11 \%$ of days with heavy rainfall, has two low-pressure centers over Europe: one over the southern Baltic and the second over the central part of the Mediterranean Sea. Neither of these are very intense, but there is an advection of humid air from the north-west to Poland.

In the third type, representative of almost $8 \%$ of selected days, there are two low-pressure systems. One in the climatological position of the Iceland Low and the second over the north-eastern part of European Russia. a high-pressure ridge is between them. Such a configuration causes the advection of humid air from the north-west to Poland. The fourth type has a zonal structure, whereby a centre of low pressure is located over the North Sea and humid air from the North Atlantic comes into Poland from the north west. This type occurs on $5.9 \%$ of days with heavy rainfall. 
Table 8. Characteristics of synoptic types distinguished by Lund method at the $700 \mathrm{hPa}$ level.

\begin{tabular}{lccc}
\hline & date & number of cases & $\%$ of cases \\
\hline 1 & 20th July 1981 & 168 & $25.9 \%$ \\
2 & 6th March 1978 & 71 & $11.0 \%$ \\
3 & 4th July 1984 & 51 & $7.9 \%$ \\
4 & 16th September 1983 & 38 & $5.9 \%$ \\
5 & 17th May 1968 & 24 & $3.7 \%$ \\
6 & 12th June 1968 & 20 & $3.1 \%$ \\
7 & 28th July 1968 & 13 & $2.0 \%$ \\
\hline
\end{tabular}

The next three types are characterized by a low-pressure system with a centre located over the southern Baltic, northern Italy and south-eastern Poland respectively. Such situations are less common and occur together in less than $10 \%$ of days.

The heavy rainfall situations in days with north-easterly or north-westerly advections are generally in agreement with the results of Niedźwiedź (Paszyński and Niedźwiedź 1999). However heavy rainfall does not occur over the whole of Poland at the same time, so interregional differences can be quite large. A denser dataset would seem to be necessary if the influence of circulation on the occurrence of extreme precipitation events is to be determined in full.

\section{SUMMARY AND DISCUSSION}

The above analysis makes it clear that precipitation in Poland did not change greatly in the second half of the 20th century. Only the frequency of wet days has increased, though the fact that this is not connected with an increase in annual totals ensures that the mean precipitation on a wet day is decreasing. These findings are consistent with the results of Kożuchowski (2004), who has demonstrated reduced rainfall intensity (mean precipitation per wet day), as well as with those of Niedźwiedź (2000) and Kożuchowski and Żmudzka (2003), indicating a rise in the number of wet days in Poland.

Unfortunately, this does not mean there is no risk of water deficit in Poland. Indeed, just the opposite results can be anticipated, since the warming entails an increase in evaporation. The analyses of temperature trends for Poland shows that air temperature is rising and will rise in future, whereas the amount of precipitation will not change significantly (Houghton et al. 2001). Such a situation will result in an increase in evaporation, ensuring that less water remains in the soil and available for runoff.

\section{ACKNOWLEDGEMENTS}

The work was supported by the Polish Ministry of Education and Science under Grant PBZ-KBN-086/PO4/2003.

\section{REFERENCES}

Degirmendžić, J., Kożuchowski, K., Marciniak, K. (2000), Zmiany temperatury powietrza i opadów atmosferycznych w Polsce miedzy dekadami 1959-1968 i 1989-1998 na tle warunków cyrkulacyjnych [Changes of air temperature and atmospheric precipitation in Poland onagainst the background of circulation conditions (1959-1968, 1989-1998)], Acta Universitatis Nicolai Copernici. Geografia, 31, 106.

Haylock, M.R. Goodess, C.M. (2004), Interannual variability of European extreme winter rainfall and links with mean largescale circulation. International Journal of Climatology, 24: 759-776.

Houghton, J.T. Ding, Y. Griggs, D.J. Nouger, M. van der Linden, P.J. Xiaosu, D. (eds.) (2001), Climate Change 2001: The Scientific Basis Contribution of Working Group 1 to the Third Assessment Report of the Intergovernmental Panel on Climate Changer, Cambridge University Press, UK, 944 pp. 
Hurrell, J.W. van Loon, H. (1997), Decadal variations in climate associated with the North Atlantic Oscillation, Climatic Change, 36:301-326.

Kalnay, E., M. Kanamitsu, R. Kistler, W. Collins, D. Deaven, L. Gandin, M. Iredell, G. White, J. Woolen, Y. Zhu, M. Chelliah, W. Ebisuzaki, W. Higgins, J. Janowiak, K. Mo, and D. Joseph, (1996), NCEP/NCAR 40-year reanalysis project. Bulletin of the American Meteorological Society, 77, 437-471.

Klein Tank, A.M.G. Können, G.P. (2003), Trends in indices of daily temperature and precipitation extremes in Europe, 1946-99. Journal of Climate, 16, 36653680 .

Kożuchowski, K. (2004), Zmienność opadów atmosferycznychwPolscewXXiXXI wieku [Variability of atmospheric precipitation in Poland in the 20th and 21th century, in Kożuchowski K. (ed.), Skala, uwarunkowania i perspektywy współczesnych zmian klimatycznych $w$ Polsce [Scale, conditions and perspectives of the contemporary climatic changes in Poland], Wydawnictwo Biblioteka, Łódź 47-58.

Kożuchowski K, Żmudzka E, (2003), 100year series of areally averaged temperatures and precipitation totals in Poland, Acta Universitatis Wratislaviensis, 2542, Studia geograficzne, 75: 116-122.

Lund, I. A. (1963), Map-pattern classification by statistical methods, Journal of Applied Meteorology and Climatology, 16:20-33. Moberg, A., Jones, P.D., Lister, D., Walther, A., Brunet, M., Jacobeit, J., Alexander, L.V., Della-Marta, P.M., Luterbacher, J., Yiou, P., Chen, D., Klein Tank, et al. (2006), Indices for daily temperature and precipitation extremes in Europe analysed for the period 1901-2000. Journal of Geophysical Research, 111: D22106.

Niedźwiedź, T. (2000), Dynamics to selected extreme climatic events in Poland, Geographia Polonica, 73, 2:25-39.
Paszyński, J., Niedźwiedź, T. (1999), Klimat, in Starkel L. (ed.), Geografia Polski - środowisko przyrodnicze [Geography of Poland - natural environment], Państwowe Wydawnictwo Naukowe (PWN), Warszawa.

Sen, P.K. (1968), Estimates of the regression coefficient based on Kendall's tau, Journal of the American Statistical Association, 63:1379-1389.

Watson RT, Zinyowera MC, Moss RH (eds.) (1998), The Regional Impacts of Climate Change: An Assessment of Vulnerability, Cambridge University Press: Cambridge, UK.

Wibig J. (1999), Precipitation in Europe in relation to circulation patterns at the 500 $\mathrm{hPa}$ level, International Journal of Climatology, 19: 253-269.

Wibig J. (2001), Wpływ cyrkulacji atmosferycznej na rozklad przestrzenny anomalii temperatury $i$ opadów $w$ Europie [The influence of atmospheric circulation on spatial distribution of temperature and precipitation anomalies in Europe], Rozprawy habilitacyjne Uniwersytetu Łódzkiego, Wydawnictwo Uniwersytetu Łódzkiego, Łódź.

Wibig J. (2004), Pole ciśnienia nad Europa $i$ pótnocnym Atlantykiem a warunki termiczne $i$ opadowe $w$ Polsce [Pressure patterns over Europe and the Northern Atlantic versus thermic and precipitation conditions in Poland] in K. Kożuchowski (ed.), Skala, uwarunkowania i perspektywy wspótczesnych zmian klimatycznych $w$ Polsce [Scale, conditions and perspectives of the contemporary climatic changes in Poland], Wydawnictwo Biblioteka, Łódź, pp. 89-120.

Paper first received: February 2007 In final form: September 2007 